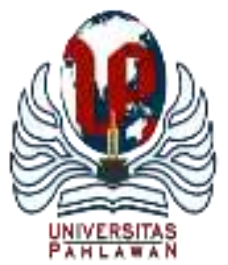

Edukatif : Jurnal Ilmu Pendidikan Volume 4 Nomor 1 Tahun 2022 Halm 1006 - 1017

EDUKATIF: JURNAL ILMU PENDIDIKAN

Research \& Learning in Education

https://edukatif.org/index.php/edukatif/index

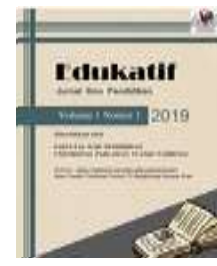

\title{
Penerapan Model Pembalajaran Predict-Observe- Explain (POE) untuk Meningkatkan Hasil Belajar Siswa
}

\author{
Hasrul $^{1 凶}$, Muh Yunus ${ }^{2}$, Husain $\mathbf{A S}^{3}$ \\ SMP Negeri 1 Liukang Tangaya Pangkep, Indonesia ${ }^{1}$ \\ Pendidikan Ekonomi, Pascasarjana STKIP Pembangunan Indonesia Makassar ${ }^{2,3}$ \\ E-mail : hasifajoin@gmail.com ${ }^{1}$, emyunusjale@gmail.com ${ }^{2}$, husainaspale@gmail.com $^{3}$
}

\begin{abstract}
Abstrak
Penelitian ini merupakan jenis Penelitian Tindakan Kelas (PTK). Penelitian bertujuan meningkatkan hasil belajar IPS siswa kelas VIII di SMPN 1 Liukang Tangaya Pangkep melalui Model Pembelajaran PredictObserve-Explain (POE). Setting penelitian meliputi perencanaan (Plenning), Tindakan (Observation), dan refleksi (reflection). Faktor yang diselidiki meliputi faktor input, faktor proses, faktor output. Teknik pengumpulan data melalui observasi, tes, dan dokumentasi. Teknik analisis data mengunakan analisis deskriptif kuantitatif. Hasil penelitian penerapan model pembelajaran Predict-Observe-Explain (POE) pada siswa kelas VIII di SMPN 1 Liukang Tangaya Pangkep mampu meningkatkan hasil belajar siswa. Hal ini tergambar dari hasil tes belajar siswa dari tiap siklusnya meningkat $100 \%$ dengan rata-rata kelas 82,66 berada pada kategori baik. Dengan demikian dapat disimpulkan bahwa penerapan Model Pembelajaran PredictObserve-Explain (POE) pada siswa kelas VIII di SMPN 1 Liukang Tangaya Pangkep memberikan dampak yang signifikan terhadap hasil belajar siswa.
\end{abstract}

Kata Kunci: Model Pembelajaran, Predict-Observe-Explain (POE), Hasil Belajar Siswa.

\begin{abstract}
This research is a type of Classroom Action Research (CAR). This study aims to improve social studies learning outcomes for grade VIII students at SMPN 1 Liukang Tangaya Pangkep through the Predict-ObserveExplain (POE) Learning Model. The research setting includes planning (Plenning), Action (Observation), and reflection (reflection). Factors investigated include input factors, process factors, output factors. Data collection techniques through observation, tests, and documentation. The data analysis technique used quantitative descriptive analysis. The results of the study applying the Predict-Observe-Explain (POE) learning model to class VIII students at SMPN 1 Liukang Tangaya Pangkep were able to improve student learning outcomes. This is illustrated by the results of student learning tests from each cycle that increased by $100 \%$ with a class average of 82.66 in the good category. Thus, it can be concluded that the application of the Predict-Observe-Explain (POE) learning model to class VIII students at SMPN 1 Liukang Tangaya Pangkep has a significant impact on student learning outcomes.
\end{abstract}

Keywords: Learning Model, Predict-Observe-Explain (POE), Student Learning Outcomes.

Copyright (c) 2022 Hasrul, Muh Yunus, Husain AS

$\checkmark$ Corresponding author

Email : hasifajoin@gmail.com

DOI $:$ https://doi.org/10.31004/edukatif.v4i1.1972

ISSN 2656-8063 (Media Cetak)

ISSN 2656-8071 (Media Online) 
1007 Penerapan Model Pembalajaran Predict-Observe- Explain (POE) untuk Meningkatkan Hasil Belajar Siswa - Hasrul, Muh Yunus, Husain AS

DOI: https://doi.org/10.31004/edukatif.v4i1.1972

\section{PENDAHULUAN}

Dalam proses pembelajaran, dunia pendidikan membutuhkan tenaga pendidik dengan keterampilan pedagogik yang unggul, keterampilan pedagogik yang memungkinkan mereka menerapkan metode pembelajaran yang efektif dan mengkomunikasikan informasi untuk kepentingan pendidikan (Ayu, 2021). Model pembelajaran adalah seperangkat kegiatan yang dapat digunakan untuk meningkatkan proses pelaksanaan, model pembelajaran merupakan salah satu alternatif untuk meningkatkan hasil belajar siswa dengan cara memungkinkan siswa dengan cepat memahami dan mempraktekkan pelajaran yang diajarkan oleh guru (Udayani \& Kusmariyatni, 2016). Siswa akan mendapatkan keuntungan dari model pembelajaran yang baik karena mereka akan belajar lebih efektif. Alasannya, model pembelajaran yang efektif akan membuat kegiatan belajar guru dan siswa lebih menyenangkan, dan hasilnya akan memuaskan (Sugiyem, 2021).

Pembelajaran siswa saat ini dapat dikatakan kurang optimal, terutama di tengah wabah Covid-19, dan sekolah yang tidak utamakan menggunakan model pembelajaran yang melibatkan siswa dalam belajar sebagai akibat dari hasil belajar yang buruk (Yunitasari \& Hanifah, 2020). Rendahnya hasil belajar siswa disebabkan oleh ketidakmampuan guru dalam menerapkan model pembelajaran yang efektif dan variatif, serta kurangnya motivasi dan fasilitas sekolah yang kurang memadai (Fitrah \& Sudarno, 2021). Faktor lain yang berkontribusi terhadap hasil belajar siswa yang buruk adalah penggunaan model atau metode yang tidak menyenangkan, seperti model cerah dan metode diskusi, dalam proses pembelajaran (Suparni, 2017). Karena proses pembelajaran dilakukan secara online dan durasi kegiatan pembelajaran sangat terbatas, maka hasil belajar siswa juga rendah karena kondisi dan keadaan saat ini. Masa Covid-19 sangat membuat hasil belajar siswa menjadi rendah karena proses pembelajaran dilakukan secara online dan durasi kegiatan pembelajaran sangat terbatas (Naibaho et al., 2021).

Setiap pembelajaran memanfaatkan model pembelajaran semaksimal mungkin untuk menjamin tercapainya hasil belajar siswa (Ikhwan et al., 2021). Hasil belajar siswa yang baik dibutuhkan seorang guru yang mampu menerapkan berbagai model yang variatif dan menyenangkan untuk kelancaran pelaksanaan pembelajaran yang terjadi agar pembelajaran siswa dapat meningkatkan hasil belajar (S et al., 2021). Supaya pembelajaran menjadi menyenangkan dan hasil belajar siswa meningkat guru haruslah bisa menerapkan berbagai model pembelajaran, seperti model pembelajaran Predict-Observe-Explain (POE) agar dapat memberikan peningkatan hasil belajar bagi siswa (Tandi \& Limbong, 2021).

Penelitian (Riyanti, 2021) Berkaitan dengan peningkatan hasil belajar siswa. Temuan penelitian mengungkapkan bahwa hasil belajar siswa yang rendah sebagai akibat dari proses pembelajaran online, sehingga perlu pengembangan model pembelajaran yang efektif untuk meningkatkan hasil belajar siswa. (Iryanto, 2021) analisis faktor-faktor yang mempengaruhi motivasi belajar siswa sekolah dasar selama pembelajaran pnline. Hasil temuan mengungkapkan bahwa rendahnya motivasi siswa disebabkan oleh kurangnya model pemeblajaran yang efektif, minat belajar, serta kesehatan fisik dan mental mereka. Akibatnya, hasil belajar siswa menjadi buruk. Permasalahan ini juga terjadi di SMP Negeri 1 Liukang Tangaya Pangkep, dimana terdapat beberapa permasalahan diantaranya hasil belajar siswa yang sangat rendah akibat pembelajaran online dan pembelajaran yang membosankan karena proses pembelajaran tidak dilakukan dengan menggunakan model atau metode yang bervariasi sehingga siswa bosan dalam mengikuti kegiatan pembelajaran. Masalah lainnya adalah guru tidak efektif menggunakan model, ceramah, dan diskusi untuk melaksanakan pembelajaran.

Signifikansi penelitian ini dilakukan dalam bidang pendidikan agar tenaga pengajar lebih memperhatikan keterampilannya dalam melaksanakan pembelajaran dengan menggunakan berbagai model atau metode yang menyenangkan agar siswa lebih antusias dalam mengikuti pembelajaran, kegiatan yang dilakukan dalam rangka meningkatkan hasil belajar yang baik. Karena hasil belajar siswa merupakan tujuan 
1008 Penerapan Model Pembalajaran Predict-Observe- Explain (POE) untuk Meningkatkan Hasil Belajar Siswa - Hasrul, Muh Yunus, Husain AS

DOI: https://doi.org/10.31004/edukatif.v4i1.1972

pendidikan, maka hasil belajar siswa harus ditingkatkan, berdasarkan observasi, siswa di SMP Negeri 1 Liukang Tangaya Pangkep masih memiliki hasil belajar yang kurang baik. Oleh karena itu, peneliti memutuskan untuk melanjutkan penelitian tentang "Penggunaan Model Pembelajaran Predict-ObserveExplain (POE) untuk Meningkatkan Hasil Belajar Siswa di SMP Negeri 1 Liukang Tangaya Pangkep, Sulawesi Selatan".

\section{METODE PENELITIAN}

Penelitian ini dilaksanakan di SMP Negeri 1 Liukang Tangaya Kabupaten Pangkep Sulawesi Selatan, pada bulan Oktober hingga September 2021. Penelitian ini merupakan Penelitian Tindakan Kelas (PTK). Setting penelitian dilakukan dalam beberapa tahap, meliputi perencanaan (Plenning), Tindakan (Observation), dan refleksi (reflection) yang dirangkai dalam siklus kegiatan. Penelitian ini dilakukan pada hasil pembelajaran IPS siswa kelas VIII pada semester ganjil tahun pelajaran 2020/2021. Subjek penelitian siswa kelas SMPN 1 Liukang Tangaya Pangkep sebanyak 15 siswa. Adapun faktor yang diselidiki berikut:

- Faktor Input

- Faktor Proses

- Faktor Output

Prosedur dalam penelitian ini yakni sebelum melakukan penelitian, peneliti melakukan observasi terlebih dahulu untuk dijadikan acuan atau dasar pada penelitian tindakan kelas. Pada siklus I jika aktivitas dan hasil belajar belum mencapai indikator keberhasilan, maka akan dilanjutkan dengan refleksi untuk pelaksanaan siklus II. Jika pada siklus II masih belum terjadi peningkatan aktivitas dan hasil belajar, maka dilakukan refleksi untuk melanjutkan ke siklus berikutnya sampai mencapai indikator keberhasilan. Adapun gambaran model spiral dari Kemis dan Tagrt, berikut:

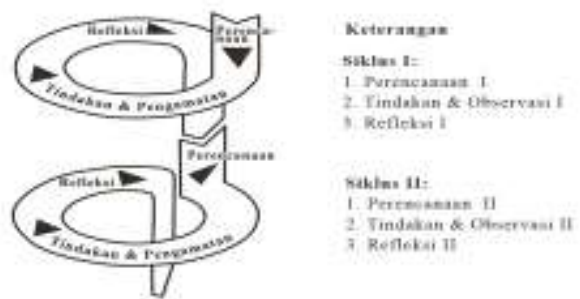

Gambar 1

Teknik pengumpulan data melalui observasi, tes, dan dokumentasi. Teknik analisis data mengunakan analisis deskriptif kuantitatif, yakni data dianalisis dengan memberi pertimbangan-pertimbangan, memberi komentar-komentar, mengklasifikasikan data, mencari hubungan-hubungan, mencari perbandinganperbandingan, mengkategorikan data dan selanjutnya membuat kesimpulan refleksi dengan mencari makna dari kesimpulan hubungan antar kategori, Hasil belajar siswa diukur dengan menggunakan teknik tes. Tes diberikan pada akhir tiap siklus sebanyak 25 butir soal. Adapun pedoman penskoran masing-masing butir soal dapat dilihat pada tabel 1 berikut:

Tabel 1. Pedoman Penskoran Tes Hasil Belajar

\begin{tabular}{cccc}
\hline No & Jenis Soal & Skor Tiap Soal & Skor Maksimal \\
\hline $1-10$ & Pilihan Ganda & 10 & 100 \\
\hline
\end{tabular}


1009 Penerapan Model Pembalajaran Predict-Observe- Explain (POE) untuk Meningkatkan Hasil Belajar Siswa - Hasrul, Muh Yunus, Husain AS

DOI: https://doi.org/10.31004/edukatif.v4i1.1972

Indikator keberhasilan dalam penelitian ini ditunjukkan untuk meningkatnya hasil belajar siswa dalam proses pembelajaran, dapat dilihat dari peningkatan rata-rata yang diperoleh dari persentase (\%) model pembelajaran POE siswa selama proses pembelajaran. Apabila mencapai $70 \%$ dari jumlah siswa maka penerapan model pembelajaran POE dapat meningkatkan pembelajaran.

\section{HASIL DAN PEMBAHASAN PENELITIAN}

Tabel 2. Hasil Observasi Aktivitas Mengajar Guru Siklus I

\begin{tabular}{|c|c|c|c|c|c|c|}
\hline \multirow{3}{*}{ No } & \multirow{3}{*}{ Aspek yang Diamati } & \multicolumn{5}{|c|}{ Kualifikasi } \\
\hline & & \multicolumn{3}{|c|}{$\begin{array}{c}\text { Pertemuan } \\
1\end{array}$} & \multicolumn{2}{|c|}{$\begin{array}{c}\text { Pertemuan } \\
\quad 2\end{array}$} \\
\hline & & $\mathbf{B}$ & $\mathbf{C}$ & $\mathbf{K}$ & B & $\mathbf{C} \quad \mathbf{K}$ \\
\hline 1. & Memberikan pertanyaan awal atau apersepsi & & $\sqrt{ }$ & & $\sqrt{ }$ & \\
\hline 2. & Membagi siswa menjadi beberapa kelompok & & $\sqrt{ }$ & & $\sqrt{ }$ & \\
\hline 3. & $\begin{array}{l}\text { Memberikan dan membimbing peserta didik } \\
\text { menjawab lembar prediksi. }\end{array}$ & $\sqrt{ }$ & & & $\sqrt{ }$ & \\
\hline 4. & Memfasilitasi siswa melakukan pengamatan & & & $\sqrt{ }$ & & $\sqrt{ }$ \\
\hline 5. & Menjelaskan langkah-langkah pengamatan & & $\sqrt{ }$ & & & $\sqrt{ }$ \\
\hline 6. & $\begin{array}{l}\text { Membimbing peserta didik untuk melakukan } \\
\text { diskusi hasil pengamatan. }\end{array}$ & & & & & $\sqrt{ }$ \\
\hline 7. & Mengamati proses pengamatan peserta didik & & $\sqrt{ }$ & & & $\sqrt{ }$ \\
\hline 8. & $\begin{array}{l}\text { Membimbing peserta didik untuk } \\
\text { mempresentasikan hasil pengamatan }\end{array}$ & & & $\sqrt{ }$ & & $\sqrt{ }$ \\
\hline 9. & $\begin{array}{l}\text { Memberikan penguatan konsep tentang materi } \\
\text { yang dipelajari }\end{array}$ & & $\sqrt{ }$ & & & $\sqrt{ }$ \\
\hline 10. & $\begin{array}{l}\text { Memberikan kesempatan kepada peserta didik } \\
\text { untuk bertanya. }\end{array}$ & & $\sqrt{ }$ & & & $\sqrt{ }$ \\
\hline 11. & $\begin{array}{l}\text { Meminta siswa megumpulkan lembar jurnal } \\
\text { dan lembar prediksi. }\end{array}$ & $\sqrt{ }$ & & & $\sqrt{ }$ & \\
\hline 12. & Membimbing siswa untuk menuliskan refleksi & & & $\sqrt{ }$ & & $\sqrt{ }$ \\
\hline 13. & $\begin{array}{l}\text { Menyampaikan materi dan kegiatan yang akan } \\
\text { dilakukan pada pertemuan selanjutnya. }\end{array}$ & & & $\sqrt{ }$ & & $\sqrt{ }$ \\
\hline
\end{tabular}

Tabel 2. di atas hasil observasi aktivitas mengajar guru pada pembelajaran IPS dengan penerapan model pembelajaran Predict-Observe-Explain ( POE ) pada siklus I pertemuan 1 dapat diuraikan sebagai berikut: a) Aspek memberikan pertanyaan awala terkategori cukup, b) Aspek membagi siswa menjadi beberapa kelompok terkategori baik, c) Aspek memberikan dan membimbing peserta didik menjawab lembar prediksii terkategori baik, d) Aspek memfasilitasi siswa melakukan pengamatan berupa penyediaan alat dan bahan yang ada di sekolah terkategori kurang, e) Aspek membimbing peserta didik untuk melakukan diskusi hasil pengamatan terkategori cukup, f) Aspek membimbing peserta didik untuk mempresentasikan hasil pengamatan terkategori kurang, g) Aspek memberikan penguatan konsep tentang materi yang dipelajari terkategori cukup, h) Aspek memberikan kesempatan kepada peserta didik untuk bertanya.terkategori cukup, i) Aspek meminta siswa megumpulkan lembar jurnal dan lembar prediksi terkategori baik, i) Aspek membimbing siswa untuk menuliskan refleksi terkategori cukup, j) Aspek menyampaikan materi dan kegiatan yang akan dilakukan pada pertemuan selanjutnya terkategori kurang. Dengan demikian dapat disimpulkan bahwa seluruh aspek aktivitas guru dengan penerapan model pembelajaran Predict-Observe-Explain ( POE )) 
1010 Penerapan Model Pembalajaran Predict-Observe- Explain (POE) untuk Meningkatkan Hasil Belajar Siswa - Hasrul, Muh Yunus, Husain AS

DOI: https://doi.org/10.31004/edukatif.v4i1.1972

dalam proses pembelajaran IPS pada siklus I pertemuan 1, tiga aspek yang terkategori baik, enam aspek terkategori cukup, dan empat aspek terkategori kurang.

Tabel 3. Hasil Observasi Aktivitas Belajar Siswa pada Siklus I Pertemuan 1

\begin{tabular}{|c|c|c|c|c|c|c|c|}
\hline \multirow{2}{*}{ No. } & \multirow{2}{*}{ Aspek yang Diamati } & \multicolumn{2}{|c|}{ Baik } & \multicolumn{2}{|c|}{ Cukup } & \multicolumn{2}{|c|}{ Kurang } \\
\hline & & $f$ & $\%$ & $F$ & $\%$ & $f$ & $\%$ \\
\hline 1 & $\begin{array}{l}\text { Menuliskan hasil prediksi pada } \\
\text { lembar prediksi }\end{array}$ & 4 & 26,66 & 4 & 26,66 & 7 & 46,66 \\
\hline 2 & $\begin{array}{l}\text { Melakukan pengamatan secara } \\
\text { berkelompok }\end{array}$ & 4 & 26,66 & 7 & 46,66 & 4 & 26,66 \\
\hline 3 & $\begin{array}{l}\text { Berdiskusi menjawab } \\
\text { pertanyaan pada lembar kerja }\end{array}$ & 2 & 13,33 & 6 & 40 & 7 & 46,66 \\
\hline 4 & $\begin{array}{l}\text { Menuliskan kesimpulan yang } \\
\text { didapatkan dari hasil } \\
\text { pengamatan }\end{array}$ & 2 & 13,33 & 6 & 40 & 7 & 46,66 \\
\hline 5 & $\begin{array}{l}\text { Menyampaikan hasil } \\
\text { pengamatan dihadapan teman } \\
\text { kelas. }\end{array}$ & 1 & 6,66 & 7 & 46,66 & 7 & 46,66 \\
\hline
\end{tabular}

Tabel 3. di atas hasil observasi aktivitas belajar siswa pada pembelajaran IPS dengan penerapan model pembelajaran Predict-Observe-Explain ( POE ) pada siklus I pertemuan 1 dapat diuraikan sebagai berikut: a) Aspek menuliskan hasil prediksi pada lembar prediksi yang terkategori baik 26,66 \%, terkategori cukup 26,66 $\%$ dan terkategori kurang 46,66\%, b) Aspek melakukan pengamatan secara berkelompok yang terkategori baik 26,66 \%, terkategori cukup 46,66 \% dan terkategori kurang 26,66 \%, c) Aspek berdiskusi menjawab pertanyaan pada lembar kerja yang terkategori baik 13,33\%, terkategori cukup $40 \%$ dan terkategori kurang 46,66 \%, d) Aspek menuliskan kesimpulan yang didapatkan dari hasil pengamatan yang terkategori baik 13,33 $\%$, terkategori cukup $40 \%$ dan terkategori kurang 46,66 \%, e) Aspek menyampaikan hasil pengamatan dihadapan teman kelas yang terkategori baik 6,66 \%, terkategori cukup 46,66\% dan terkategori kurang 46,66 $\%$. Dari hasil tersebut dapat disimpulkan bahwa dari lima aktivitas belajar siswa pada siklus I pertemuan 1 dari lima jenis kegiatan belajar lebih dominan pada kategori kurang.

Tabel 4. Hasil Observasi Aktivitas Belajar Siswa pada Siklus I Pertemuan 2

\begin{tabular}{|c|c|c|c|c|c|c|c|}
\hline \multirow{2}{*}{ No. } & \multirow{2}{*}{ Aspek yang Diamati } & \multicolumn{2}{|c|}{ Baik } & \multicolumn{2}{|c|}{ Cukup } & \multicolumn{2}{|c|}{ Kurang } \\
\hline & & $f$ & $\%$ & $F$ & $\%$ & $f$ & $\%$ \\
\hline 1 & $\begin{array}{l}\text { Menuliskan hasil prediksi pada } \\
\text { lembar prediksi }\end{array}$ & 5 & 41,67 & 6 & 40 & 4 & 26,66 \\
\hline 2 & $\begin{array}{l}\text { Melakukan pengamatan secara } \\
\text { berkelompok }\end{array}$ & 4 & 26,66 & 7 & 53,33 & 3 & 20 \\
\hline 3 & $\begin{array}{l}\text { Berdiskusi menjawab } \\
\text { pertanyaan pada lembar kerja }\end{array}$ & 4 & 26,66 & 7 & 46,66 & 4 & 26,66 \\
\hline 4 & $\begin{array}{l}\text { Menuliskan kesimpulan yang } \\
\text { didapatkan dari hasil } \\
\text { pengamatan }\end{array}$ & 4 & 26,66 & 7 & 46,66 & 4 & 26,66 \\
\hline 5 & $\begin{array}{l}\text { Menyampaikan hasil } \\
\text { pengamatan dihadapan teman } \\
\text { kelas. }\end{array}$ & 3 & 20 & 5 & 53,33 & 7 & 46,66 \\
\hline
\end{tabular}


1011 Penerapan Model Pembalajaran Predict-Observe- Explain (POE) untuk Meningkatkan Hasil Belajar Siswa - Hasrul, Muh Yunus, Husain AS

DOI: https://doi.org/10.31004/edukatif.v4i1.1972

Tabel 4. di atas hasil observasi aktivitas belajar siswa pada pembelajaran IPS dengan penerapan model pembelajaran Predict-Observe-Explain ( POE ) pada siklus I pertemuan 2 dapat diuraikan sebagai berikut: a) Aspek menuliskan hasil prediksi pada lembar prediksi yang terkategori baik $41,67 \%$, terkategori cukup $40 \%$ dan terkategori kurang 26,66 \%, b) Aspek melakukan pengamatan secara berkelompok yang terkategori baik 26,66 \%, terkategori cukup 46,66\% dan terkategori kurang $20 \%$, c) Aspek berdiskusi menjawab pertanyaan pada lembar kerja yang terkategori baik 26,66\%, terkategori cukup 46,66 \% dan terkategori kurang 26,66\%, d) Aspek menuliskan kesimpulan yang didapatkan dari hasil pengamatan yang terkategori baik 26,66\%, terkategori cukup 46,66\% dan terkategori kurang 26,66\%, e) Aspek menyampaikan hasil pengamatan dihadapan teman kelas yang terkategori baik $20 \%$, terkategori cukup 53,33\% dan terkategori kurang 46,66\%. Paparan data hasil observasi di atas dapat disimpulkan bahwa aktivitas belajar siswa pada siklus I masih rendah, hal ini dapat dilihat dari rendahnya pencapaian aktivitas siswa masih pada kategori cukup dari hasil observasi aktivitas belajar siswa.

Tabel 5. Data Hasil Belajar Siswa pada Siklus I

\begin{tabular}{lllll}
\hline No & Tingkat Penguasaan & Kategori & Frekuensi & Persentase \\
\hline 1 & $90-100$ & Sangat Baik & 1 & 6,66 \\
\hline 2 & $80-89$ & Baik & 2 & 13,33 \\
\hline 3 & $65-79$ & Sedang & 6 & 40 \\
\hline 4 & $55-64$ & Rendah & 4 & 26,66 \\
\hline 5 & $0-54$ & Sangat Rendah & 2 & 13,33 \\
\hline Jumlah & & $\mathbf{1 5}$ & $\mathbf{1 0 0}$
\end{tabular}

Data hasil belajar siswa pada pada tabel di atas menunjukkan bahwa, pada siklus I yang memperoleh nilai 90-100 dengan kategori sangat baik sebanyak 1 orang siswa atau 6,66\%, nilai 80-89 dengan kategori baik sebanyak 2 orang siswa atau 13,33\%, nilai 65-79 dengan kategori sedang sebanyak 6 orang siswa atau 40\%, nilai 55-64 dengan kategori rendah sebanyak 4 orang siswa atau 26,66\% sedangkan nilai 0-54 dengan kategori sangat rendah sebanyak 2 orang siswa atau 13,33\%. Dari temuan data hasil belajar di atas disimpulkan bahwa yang memperoleh nilai di atas KKM yaitu 65 sebanyak 6 orang siswa atau 40\%. Hasil temuan ini masih berada di bawah batas kriteria keberhasilan penelitian yang ditentukan yaitu sebanyak $80 \%$ siswa memperoleh nilai di atas KKM yaitu 65 .

Tabel 6. Hasil Observasi Aktivitas Mengajar Guru Siklus II

\begin{tabular}{|c|c|c|c|c|c|c|}
\hline \multirow{3}{*}{ No } & \multirow{3}{*}{ Aspek yang Diamati } & \multicolumn{5}{|c|}{ Kualifikasi } \\
\hline & & \multicolumn{2}{|c|}{$\begin{array}{c}\text { Pertemuan } \\
1\end{array}$} & \multicolumn{3}{|c|}{$\begin{array}{c}\text { Pertemuan } \\
2\end{array}$} \\
\hline & & $\mathbf{B}$ & $\begin{array}{ll}\mathbf{C} & \mathbf{K}\end{array}$ & $\mathbf{B}$ & $\mathbf{C}$ & $\mathbf{K}$ \\
\hline 1. & Memberikan pertanyaan awal atau apersepsi & $\sqrt{ }$ & & $\sqrt{ }$ & & \\
\hline 2. & Membagi siswa menjadi beberapa kelompok & $\sqrt{ }$ & & $\sqrt{ }$ & & \\
\hline 3. & $\begin{array}{l}\text { Memberikan dan membimbing peserta didik } \\
\text { menjawab lembar prediksi }\end{array}$ & $\sqrt{ }$ & & $\sqrt{ }$ & & \\
\hline 4. & Memfasilitasi siswa melakukan pengamatan & $\sqrt{ }$ & & $\sqrt{ }$ & & \\
\hline 5. & Menjelaskan langkah-langkah pengamatan & $\sqrt{ }$ & & $\sqrt{ }$ & & \\
\hline 6. & $\begin{array}{l}\text { Membimbing peserta didik untuk melakukan } \\
\text { diskusi hasil pengamatan }\end{array}$ & $\sqrt{ }$ & & $\sqrt{ }$ & & \\
\hline 7. & Mengamati proses pengamatan peserta didik & $\sqrt{ }$ & & $\sqrt{ }$ & & \\
\hline
\end{tabular}




\begin{tabular}{|c|c|c|c|c|c|}
\hline \multirow{3}{*}{ No } & \multirow{3}{*}{ Aspek yang Diamati } & \multicolumn{4}{|c|}{ Kualifikasi } \\
\hline & & \multicolumn{2}{|c|}{$\begin{array}{c}\text { Pertemuan } \\
1\end{array}$} & \multicolumn{2}{|c|}{$\begin{array}{l}\text { Pertemuan } \\
\quad 2\end{array}$} \\
\hline & & $\mathbf{B}$ & $\begin{array}{ll}\mathbf{C} \\
\end{array}$ & $\mathbf{B}$ & $\begin{array}{ll}\mathbf{C} & \mathbf{K}\end{array}$ \\
\hline 8. & $\begin{array}{l}\text { Membimbing peserta didik untuk } \\
\text { mempresentasikan hasil pengamatan }\end{array}$ & $\sqrt{ }$ & & $\sqrt{ }$ & \\
\hline 9. & $\begin{array}{l}\text { Memberikan penguatan konsep tentang materi } \\
\text { yang dipelajari }\end{array}$ & & $\sqrt{ }$ & $\sqrt{ }$ & \\
\hline 10 & $\begin{array}{l}\text { Memberikan kesempatan kepada peserta didik } \\
\text { untuk bertanya. }\end{array}$ & $\sqrt{ }$ & & $\sqrt{ }$ & \\
\hline 11 & $\begin{array}{l}\text { Meminta siswa megumpulkan lembar jurnal } \\
\text { dan lembar prediksi. }\end{array}$ & $\sqrt{ }$ & & $\sqrt{ }$ & \\
\hline $\begin{array}{c}12 \\
.\end{array}$ & Membimbing siswa untuk menuliskan refleksi & & $\sqrt{ }$ & $\sqrt{ }$ & \\
\hline $\begin{array}{c}13 \\
.\end{array}$ & $\begin{array}{l}\text { Menyampaikan materi dan kegiatan yang akan } \\
\text { dilakukan pada pertemuan selanjutnya. }\end{array}$ & $\sqrt{ }$ & & $\sqrt{ }$ & \\
\hline
\end{tabular}

Tabel 6. di atas hasil observasi aktivitas mengajar guru pada pembelajaran IPS dengan penerapan model pembelajaran Predict-Observe-Explain ( $P O E$ ) pada siklus II pertemuan 1 dapat diuraikan sebagai berikut: a) Aspek memberikan pertanyaan awala terkategori baik, b) Aspek membagi siswa menjadi beberapa kelompok terkategori baik, c) Aspek memberikan dan membimbing peserta didik menjawab lembar prediksii terkategori baik, d) Aspek memfasilitasi siswa melakukan pengamatan berupa penyediaan alat dan bahan yang ada di sekolah terkategori baik, e) Aspek membimbing peserta didik untuk melakukan diskusi hasil pengamatan terkategori cukup, f) Aspek membimbing peserta didik untuk mempresentasikan hasil pengamatan terkategori cukup, g) Aspek memberikan penguatan konsep tentang materi yang dipelajari terkategori cukup, h) Aspek memberikan kesempatan kepada peserta didik untuk bertanya.terkategori baik, i) Aspek meminta siswa megumpulkan lembar jurnal dan lembar prediksi terkategori baik, j) Aspek membimbing siswa untuk menuliskan refleksi terkategori cukup, k) Aspek menyampaikan materi dan kegiatan yang akan dilakukan pada pertemuan selanjutnya terkategori baik. Dengan demikian dapat disimpulkan bahwa seluruh aspek aktivitas guru dengan penerapan model pembelajaran Predict-Observe-Explain ( POE ) dalam proses pembelajaran IPS pada siklus II pertemuan 1, sepuluh aspek yang terkategori baik, tiga aspek terkategori cukup, dan tidak ada aspek terkategori kurang.

Tabel 7. Hasil Observasi Aktivitas Belajar Siswa pada Siklus II Pertemuan 1

\begin{tabular}{clcccccc}
\hline \multirow{2}{*}{ No. } & \multicolumn{1}{c}{ Aspek yang Diamati } & \multicolumn{2}{c}{ Baik } & \multicolumn{2}{c}{ Cukup } & \multicolumn{2}{c}{ Kurang } \\
\cline { 2 - 7 } & $\boldsymbol{F}$ & $\mathbf{\%}$ & $\boldsymbol{f}$ & $\mathbf{\%}$ & $\boldsymbol{f}$ & $\mathbf{\%}$ \\
\hline 1 & $\begin{array}{l}\text { Menuliskan hasil prediksi pada } \\
\text { lembar prediksi }\end{array}$ & 9 & 60 & 6 & 40 & 0 & 0 \\
\hline 2 & $\begin{array}{l}\text { Melakukan pengamatan secara } \\
\text { berkelompok }\end{array}$ & 8 & 53,33 & 7 & 46,66 & 0 & 0 \\
\hline 3 & $\begin{array}{l}\text { Berdiskusi menjawab } \\
\text { pertanyaan pada lembar kerja }\end{array}$ & 6 & 40 & 8 & 53,33 & 1 & 6,66 \\
\hline 4 & $\begin{array}{l}\text { Menuliskan kesimpulan yang } \\
\text { didapatkan dari hasil } \\
\text { pengamatan }\end{array}$ & 6 & 40 & 8 & 53,33 & 1 & 6,66 \\
\hline
\end{tabular}


1013 Penerapan Model Pembalajaran Predict-Observe- Explain (POE) untuk Meningkatkan Hasil Belajar Siswa - Hasrul, Muh Yunus, Husain AS

DOI: https://doi.org/10.31004/edukatif.v4i1.1972

\begin{tabular}{llllllll}
\hline 5 & $\begin{array}{l}\text { Menyampaikan hasil } \\
\text { pengamatan dihadapan teman } \\
\text { kelas. }\end{array}$ & 5 & 33,33 & 9 & 60 & 1 & 6,66 \\
\end{tabular}

Tabel 7. di atas hasil observasi aktivitas belajar siswa pada pembelajaran IPS dengan penerapan model pembelajaran Predict-Observe-Explain ( $P O E$ ) pada siklus II pertemuan 1 dapat diuraikan sebagai berikut: a) Aspek menuliskan hasil prediksi pada lembar prediksi yang terkategori baik $60 \%$, terkategori cukup $40 \%$ dan terkategori kurang $0 \%$, b) Aspek melakukan pengamatan secara berkelompok yang terkategori baik 53,33\%, terkategori cukup 46,66 \% dan terkategori kurang $0 \%$, c) Aspek berdiskusi menjawab pertanyaan pada lembar kerja yang terkategori baik $40 \%$, terkategori cukup 53,33\% dan terkategori kurang 6,66 \%, d) Aspek menuliskan kesimpulan yang didapatkan dari hasil pengamatan yang terkategori baik $40 \%$, terkategori cukup $53,33 \%$ dan terkategori kurang 6,66 \%, e) Aspek menyampaikan hasil pengamatan dihadapan teman kelas yang terkategori baik 33,33\%, terkategori cukup $60 \%$ dan terkategori kurang 6,66\%. Dari hasil tersebut dapat disimpulkan bahwa dari lima aktivitas belajar siswa pada siklus I pertemuan 1 dari lima jenis kegiatan belajar lebih dominan pada kategori cukup.

Tabel 8. Hasil Observasi Aktivitas Belajar Siswa pada Siklus I Pertemuan 2

\begin{tabular}{clcccccc}
\hline \multirow{2}{*}{ No. } & \multicolumn{1}{c}{ Aspek yang Diamati } & \multicolumn{2}{c}{ Baik } & \multicolumn{2}{c}{ Cukup } & \multicolumn{2}{c}{ Kurang } \\
\cline { 2 - 7 } & $\boldsymbol{F}$ & $\mathbf{\%}$ & $\boldsymbol{f}$ & $\mathbf{\%}$ & $\boldsymbol{f}$ & $\boldsymbol{\%}$ \\
\hline 1 & $\begin{array}{l}\text { Menuliskan hasil prediksi pada } \\
\text { lembar prediksi }\end{array}$ & 12 & 80 & 3 & 20 & 0 & 0 \\
\hline 2 & $\begin{array}{l}\text { Melakukan pengamatan secara } \\
\text { berkelompok }\end{array}$ & 11 & 73,33 & 4 & 26,66 & 0 & 0 \\
\hline 3 & $\begin{array}{l}\text { Berdiskusi menjawab pertanyaan } \\
\text { pada lembar kerja }\end{array}$ & 8 & 53,33 & 7 & 46,66 & 0 & 0 \\
\hline 4 & $\begin{array}{l}\text { Menuliskan kesimpulan yang } \\
\text { didapatkan dari hasil pengamatan }\end{array}$ & 8 & 53,33 & 7 & 46,66 & 0 & 0 \\
\hline 5 & $\begin{array}{l}\text { Menyampaikan hasil pengamatan } \\
\text { dihadapan teman kelas. }\end{array}$ & 8 & 53,33 & 7 & 46,66 & 0 & 0 \\
\hline
\end{tabular}

Tabel 8. di atas hasil observasi aktivitas belajar siswa pada pembelajaran IPS dengan penerapan model pembelajaran Predict-Observe-Explain ( $P O E$ ) pada siklus II pertemuan 2 dapat diuraikan sebagai berikut: a) Aspek menuliskan hasil prediksi pada lembar prediksi yang terkategori baik $80 \%$, terkategori cukup $20 \%$ dan terkategori kurang $0 \%$, b) Aspek melakukan pengamatan secara berkelompok yang terkategori baik 73,33 \%, terkategori cukup 26,66\% dan terkategori kurang $0 \%$, c) Aspek berdiskusi menjawab pertanyaan pada lembar kerja yang terkategori baik 53,33\%, terkategori cukup 46,66 \% dan terkategori kurang $0 \%$, d) Aspek menuliskan kesimpulan yang didapatkan dari hasil pengamatan yang terkategori baik $53,33 \%$, terkategori cukup 46,66\% dan terkategori kurang $0 \%$, e) Aspek menyampaikan hasil pengamatan dihadapan teman kelas yang terkategori baik 53,33\%, terkategori cukup 46,66 \% dan terkategori kurang $0 \%$. Dengan demikian dapat ditarik kesimpulan bahwa aktivitas belajar siswa pada siklus II pertemuan 2 sudah menunjukkan peningkatan partisipasi belajar yang baik, dimana semua aspek yang menjadi bahan pengamatan sudah tdak ada yang terkategori kurang.

Tabel 9. Data Hasil Belajar Siswa pada Siklus II

\begin{tabular}{lllll}
\hline No & Tingkat Penguasaan & Kategori & Frekuensi & Persentase \\
\hline 1 & $90-100$ & Sangat Baik & 5 & 33,33 \\
\hline 2 & $80-89$ & Baik & 7 & 46,66 \\
\hline 3 & $65-79$ & Sedang & 3 & 20 \\
\hline
\end{tabular}


1014 Penerapan Model Pembalajaran Predict-Observe- Explain (POE) untuk Meningkatkan Hasil Belajar Siswa - Hasrul, Muh Yunus, Husain AS

DOI: https://doi.org/10.31004/edukatif.v4i1.1972

\begin{tabular}{lllll}
4 & $55-64$ & Rendah & 0 & 0 \\
\hline 5 & $0-54$ & Sangat Rendah & 0 & 0 \\
\hline Jumlah & & $\mathbf{1 5}$ & $\mathbf{1 0 0}$
\end{tabular}

Data hasil belajar siswa pada pada tabel 9 menunjukkan bahwa, pada siklus II yang memperoleh nilai 90-100 dengan kategori sangat baik sebanyak 5 orang siswa atau 33,33\%, nilai 80-89 dengan kategori baik sebanyak 7 orang siswa atau 46,66\%, nilai 65-79 dengan kategori sedang sebanyak 3 orang siswa atau $20 \%$, nilai 55-64 dengan kategori rendah sebanyak 0 orang siswa atau $0 \%$ sedangkan nilai 0-54 dengan kategori sangat rendah sebanyak 0 orang siswa atau $0 \%$. Dari temuan data hasil belajar di atas disimpulkan bahwa yang semua siswa telah memperoleh nilai di atas KKM. Maka kriteria keberhasilan penelitian yang ditentukan yaitu sebanyak $80 \%$ siswa memperoleh nilai di atas KKM yaitu 65 telah tercapai.

Tabel 10. Data Hasil Belajar Siswa Siklus I dan Siklus II

\begin{tabular}{ccc}
\hline $\begin{array}{c}\text { Rentang } \\
\text { Nilai/Kualifikasi }\end{array}$ & Siklus I & Siklus II \\
\hline $90-100$ & 1 & 5 \\
\hline $80-89$ & 2 & 7 \\
\hline $65-79$ & 6 & 3 \\
\hline $55-64$ & 4 & 0 \\
\hline $0-54$ & 2 & 0 \\
\hline Jumlah Nilai & 1.010 & 82,66 \\
\hline Rata-Rata Nilai & 67,33 & 100 \\
\hline Ketuntasan (\%) & 60 & 0
\end{tabular}

Data hasil belajar tabel 10 di atas dapat di jelaskan bahwa yang memperoleh nilai 90-100 pada siklus I sebanyak 1 orang siswa meningkat menjadi 5 orang siswa pada siklus II. Perolehan nilai 80-89 pada siklus I sebanyak 2 orang siswa meningkat menjadi 7 orang siswa pada siklus II. Perolehan nilai 65-79 pada siklus I sebanyak 6 orang siswa menjadi sebanyak 3 orang siswa pada siklus II. Perolehan nilai 55-64 pada siklus I sebanyak 4 orang siswa menurun menjadi 0 orang siswa pada siklus II. Perolehan nilai 0-54 sebanyak 2 orang siswa siswa pada siklus I menjadi 0 orang pada siklus II.

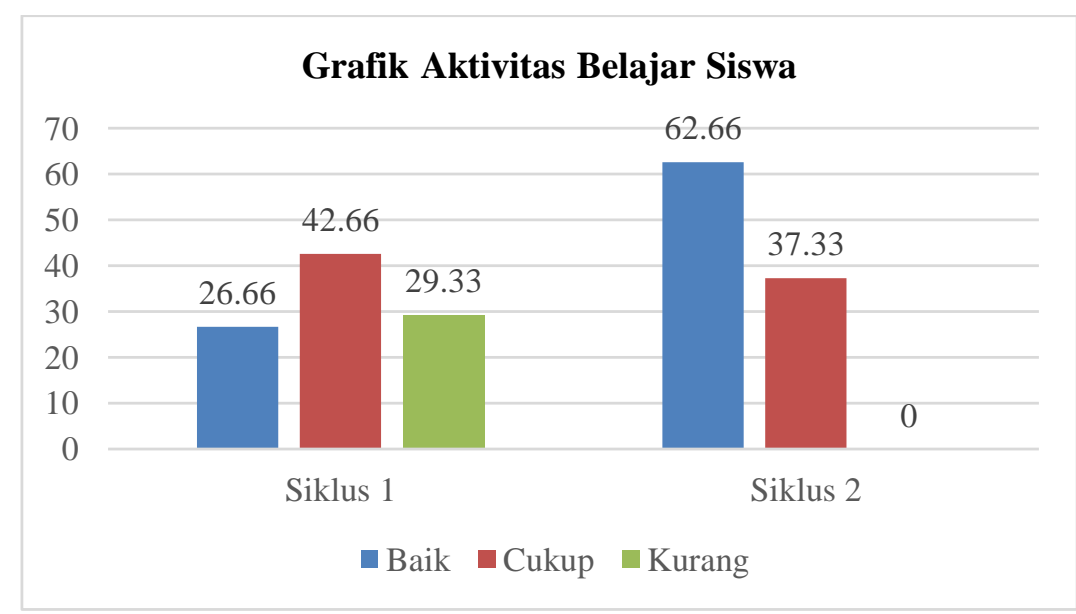

Gambar 2. Grafik Aktivitas Belajar Siswa per Siklus 
Beberapa temuan pada siklus I dari aspek siswa yang terjadi selama pembelajaran memang terbukti di antaranya adanya kecenderungan segelintir siswa tidak bersungguh-sungguh atau bermain-main dan cukup menghabiskan waktu pembelajaran sehingga kurang teralokasi untuk penajaman materi pembelajaran melalui kegiatan kulminasi dan umpan balik yang harus dilakukan guru.

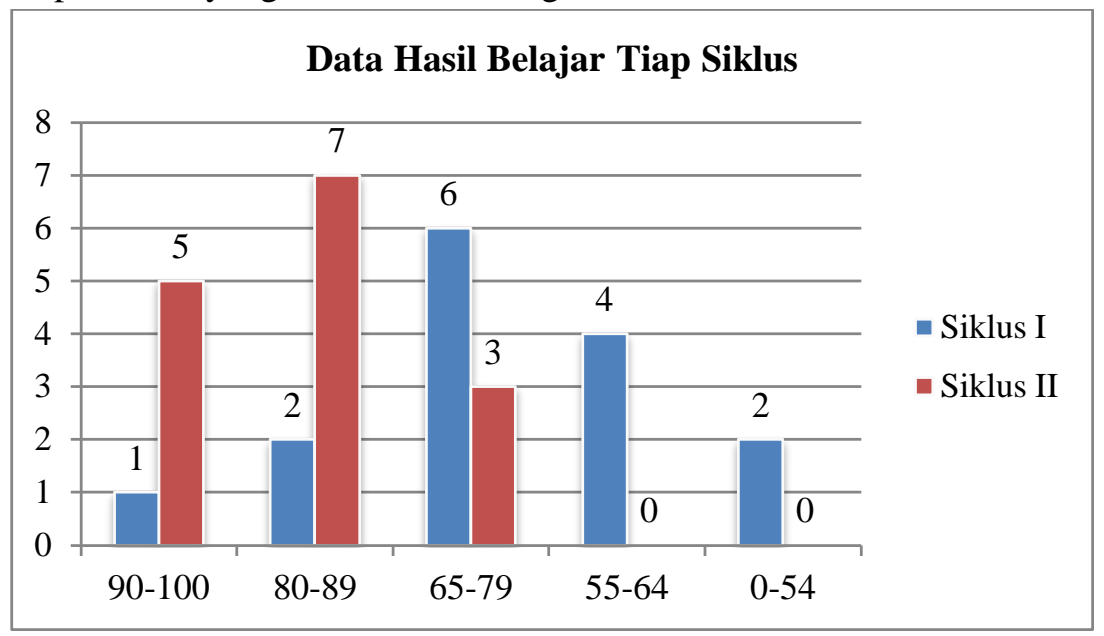

Gambar 3. Grafik Data Hasil Belajar Siklus I dan Siklus II

Dari grafik 4.2 diatas diperoleh kesimpulan tentang hasil belajar IPS siswa Kelas VIII di SMPN 1 Liukang Tangaya Pangkep dengan menerapkan model pembelajaran Predict-Observe-Explain ( POE ) menunjukkan bahwa data awal hasil belajar IPS siswa $40 \%$ atau 6 orang anak yang memperoleh nilai di bawah 65 dengan nilai rata-rata siswa siklus I. Selanjutnya pada siklus II siswa yang memperoleh nilai <65 sebanyak $0 \%$ atau 0 orang.

\section{Peningkatan Aktivitas Belajar Ips Melalui Penerapan Model Pembelajaran Predict-Observe-Explain (POE)}

Dari hasil observasi, rata-rata aktivitas belajar siswa dapat dijelaskan bahwa pada aspek menuliskan hasil prediksi pada lembar prediksi yang terkategori baik kategori baik pada siklus I sebesar 47,67\%, naik menjadi menjadi $60 \%$ pada siklus II. Untuk kategori cukup pada siklus I sebesar $40 \%$, tetap $40 \%$ pada siklus II. Untuk kategori kurang pada siklus I sebesar 26,66 \% turun menjadi $0 \%$ pada siklus II. Hal ini sejalan dengan (Rahayu \& Sutarno, 2020) menurut pasal tersebut, siswa akan dapat meningkatkan hasil belajarnya jika menggunakan model pembelajaran. Hal ini dikarenakan model pembelajaran merupakan alat untuk mengatur kegiatan pembelajaran agar lebih terarah dan terstruktur, serta memotivasi siswa untuk melaksanakan pembelajaran dimanapun berada. (Rizki Wahyuningtyas, 2020) mengatakan bahwa diperlukan berbagai media, model, dan metode dalam pelaksanaan kegiatan pembelajaran guna meningkatkan hasil belajar siswa. Siswa akan sangat antusias dalam meningkatkan hasil belajarnya jika memiliki media, model dan metode pembelajaran yang baik. Akibatnya, seorang guru harus mampu meningkatkan keterampilannya dalam berbagai media, model, dan metode dalam proses pembelajaran yang ingin dicapainya.

Penelitian (Khayat, 2021) meningkatkan hasil belajar IPS bagi siswa Temuan penelitian mengungkapkan bahwa hasil belajar siswa kurang ideal sebelum penerapan model pembelajaran dalam kegiatan belajar mengajar. Hasil belajar siswa meningkat setelah menggunakan model pembelajaran untuk melakukan kegiatan pembelajaran. Disimpulkan bahwa penggunaan model pembelajaran yang efektif akan memberikan dampak yang signifikan dan meningkatkan hasil belajar siswa. Penelitian (Suwarno et al., 2022) hubungannya dengan meningkatkan hasil belajar siswa. hasil temuan menujukan bahwa setelah menerapkan model pembelajaran hasil belajar siswa meningkat. Dengan kata lain model pembelajaran saat ini memegang peranan penting dalam pencapaian tujuan pendidikan seperti peningkatan hasil belajar siswa. 
1016 Penerapan Model Pembalajaran Predict-Observe- Explain (POE) untuk Meningkatkan Hasil Belajar Siswa - Hasrul, Muh Yunus, Husain AS

DOI: https://doi.org/10.31004/edukatif.v4i1.1972

\section{Peningkatan Hasil Belajar IPS melalui Penerapan Model Pembelajaran Predict-Observe-Explain ( POE )}

Dari hasil belajar siswa dapat dijelaskan siswa yang memperoleh nilai pada rentang 90-100 pada siklus I sebanyak 1 orang atau 6,66\% naik menjadi 5 orang atau 33,33\% pada siklus II. Pada rentang 80-89 pada siklus I sebanyak 2 orang atau 13,33\% naik menjadi 7 orang atau 46,66 \% pada siklus II. Pada rentang 65-79 pada siklus I sebanyak 6 orang atau $40 \%$ turun menjadi 3 orang atau $20 \%$ pada siklus III. Pada rentang 5564 pada siklus I sebanyak 4 orang atau $26,66 \%$ menjadi 0 orang atau $0 \%$ pada siklus II. Pada rentang $0-54$ pada siklus I sebanyak 2 orang atau 13,33\% menjadi 0 orang atau $0 \%$ pada siklus II. Menurut (Sinaga, 2017) mengatakan bahwa model pembelajaran yang baik akan membantu siswa belajar lebih efektif. Oleh karena itu, setiap sekolah, khususnya tenaga pengajar, harus lebih efektif dan efisien dalam menerapkan model pembelajaran yang efektif dan efisien. Menurut (Kristin \& Artikel, 2018) mengatakan bahwa model pembelajaran sebagai alternatif bagi siswa untuk meningkatkan hasil belajarnya, model pembelajaran yang efektif, dan mendorong siswa memiliki keinginan untuk belajar dengan antusias. (Irwan \& Hasnawi, 2021) juga mengatakan bahwa kegiatan pembelajaran yang berpola menarik siswa akan lebih termotivasi untuk mengikuti kegiatan pembelajaran yang terjadi seperti merapakan model pembelajaran yang baik akan berdampak positif terhadap hasil belajar siswa.

Penelitian (Andri Setiawan, Rusyani N Kusmawanti, 2020) model pembelajaran berpengaruh signifikan terhadap hasil belajar siswa; terlihat bahwa sebelum menggunakan model pembelajaran siswa merasa bosan dan tidak tertarik untuk belajar, namun setelah menggunakan model pembelajaran siswa sangat antusias dalam belajar. Dapat disimpulkan bahwa untuk meningkatkan hasil belajar siswa, guru harus menerapkan model pembelajaran yang efektif yang memotivasi siswa untuk meningkatkan kinerjanya.

\section{KESIMPULAN}

Kesimpulan dari penelitian tindakan kelas (PTK) ini adalah penerapan model pembelajaran PredictObserve-Explain (POE) dapat meningkatkan hasil belajar siswa kelas VIII di SMPN 1 Liukang Tangaya Pangkep berdasarkan pemaparan data dan pembahasan hasil penelitian. Hal ini dibuktikan dengan hasil tes belajar meningkat sebesar 100\%, dengan rata-rata skor tes hasil belajar 82,66 termasuk dalam kategori baik.

\section{UCAPAN TERIMA KASIH}

Ucapan terima kasih kepada Dr. Muh Yunus, M.Pd dan Dr. Husain AS, M.Pd, selaku pembimbing yang telah memberikan arahan dalam penyusunan tesis ini, terima kasih kepada pihak sekolah SMP Negeri 1 Liukang Tangaya Pangkep yang telah memberikan izin kepada peneliti.

\section{DAFTAR PUSTAKA}

Andri Setiawan, Rusyani N Kusmawanti, D. F. P. (2020). Meningkatkan Hasil Belajar IPS Pada Siswa SD Kelas IV Melalui Model Pembelajaran Kooperatif Tipe Make A Match. COLLASE Journal Of Elementary Education, 03(01), 12-18.

Ayu, N. P. (2021). PENDIDIKAN Pengaruh Metode Blended Learning Dalam Meningkatkan Motivasi Dan Hasil Belajar Siswa Sekolah Dasar. Edukatif: Jurnal Ilmu Pendidikan, 3(5), 1993-2000.

Fitrah, Y., \& Sudarno, D. (2021). MSI Transaction On Education Identifikasi Penyebab Rendahnya Intensitas Belajar Siswa Studi Kasus : Mata Diklat Perawatan Engine Dan Unit Alat Berat Kelas XI Teknik Alat Berat Di SMK Negeri 2 Payakumbuh MSI Transaction On Education. MSI Transaction On Education, 02(03). 
1017 Penerapan Model Pembalajaran Predict-Observe- Explain (POE) untuk Meningkatkan Hasil Belajar Siswa - Hasrul, Muh Yunus, Husain AS

DOI: https://doi.org/10.31004/edukatif.v4i1.1972

Ikhwan, A., Huda, N., \& Abduh, M. (2021). Pendidikan Peningkatan Hasil Belajar Menggunakan Model Pembelajaran Problem Based Learning Pada Siswa Sekolah Dasar. Edukatif: Jurnal Ilmu Pendidikan, 3(4), 1594-1601.

Irwan, I., \& Hasnawi, H. (2021). Analisis Model Pembelajaran Contextual Teaching And Learning Dalam Meningkatkan Hasil Belajar Ppkn Di Sekolah Dasar. Edukatif: Jurnal Ilmu Pendidikan, 3(1), 235-245. Https://Doi.Org/10.31004/Edukatif.V3i1.343

Iryanto, N. D. (2021). Analisis Faktor Penyebab Rendahnya Motivasi Belajar Siswa Sekolah Dasar Selama Pembelajaran Daring. Jurnal Basicedu, 5(5), 3829-3840.

Khayat, Z. (2021). Meningkatkan Hasil Belajar IPA Konsep Listrik Dinamis Dengan Model Induksi Siswa. Cendekia Jurnal Ilmu Pengatahuan, 1(1), 132-139.

Kristin, F., \& Artikel, I. (2018). Meta-Analisis Pengaruh Model Pembelajaran Role Playing Terhadap Hasil Belajar Ips. JURNAL REFLEKSI EDUKATIKA, 8(2), 2-6.

Naibaho, S. W., Siregar, E. Y., \& Elindra, R. (2021). Analisis Faktor-Faktor Penyebab Rendahnya Motivasi Belajar Siswa Mts Negeri 1 Tapanuli Tengah Disaat Pandemi Covid-19. JURNAL Mathedu (Mathematic Education Journal), 4(2), 304-312. Https://Doi.Org/10.37081/Mathedu.V4i2.2596

Rahayu, A. S., \& Sutarno, J. (2020). Meningkatkan Hasil Belajar Siswa Konsep Laju Reaksi Dengan Model Discovery Pjbl Berbasis STEM Di SMAN 1 Lemahabang Cirebon. Jurnal Pendidikan Fisika Dan Sains (JPFS), 3(2), 17-23.

Riyanti, Y. W. S. (2021). Edukatif : Jurnal Ilmu Pendidikan Pengaruh Kemandirian Belajar Terhadap Hasil Belajar Matematika Siswa Sekolah Dasar. Edukatif: Jurnal Ilmu Pendidikan, 3(4), 1309-1317.

Rizki Wahyuningtyas, B. S. S. (2020). Pentingnya Media Dalam Pembelajaran Guna Meningkatkan Hasil Belajar Di Sekolah Dasar. Jurnal Ilmu Pendidikan, 4(2), 318-333.

S, M., Raida, S. A., \& Putra, S. H. J. (2021). Pembelajaran Picture And Picture Untuk Meningkatkan Motivasi Dan Hasil Belajar Siswa Pada Materi Invertebrata. Journal Of Biology Education, 4(1), 72. Https://Doi.Org/10.21043/Jobe.V4i1.9796

Sinaga, T. (2017). Meningkatkan Hasil Belajar IPS Melalui Model Pembelajaran Think Pair Share. Jurnal Global Edukasi, I(3), 443-446.

Sugiyem. (2021). Penggunaan Model Pembelajaran STAD Untuk Meningkatkan Hasil Belajar Materi Manfaat Energi Matahari Dalam Kehidupan Sehari-Hari Pada Siswa Kelas IV SD Negeri 2 Mlokowetan Kecamatan Ngadirojo Tahun Pelajaran 2019 / 2020. Jurnal Ilmiah Guru Indonesia, 2(1), 65-75.

Suparni, S. (2017). Meningkatkan Hasil Belajar Siswa Dengan Pembelajaran Berbasis Masalah. JPPI (Jurnal Penelitian Pendidikan Indonesia), 3(1), 36. Https://Doi.Org/10.29210/02017107

Suwarno, T., Noviyanto, H., Susanti, B. H., \& Khairunnisa, S. (2022). PENDIDIKAN Penerapan Model Pembelajaran Kooperatif Tipe Make A Match Untuk Meningkatkan Hasil Belajar Biologi. Edukatif: Jurnal Ilmu Pendidikan, 4(1), 572-581.

Tandi, M., \& Limbong, M. (2021). Evaluasi Hasil Belajar Siswa Sma Kristen Barana' Pada Pembelajaran Tatap Muka Di Masa New Normal. Jurnal Manajemen Pendidikan, 10(1), 13-20. Https://Doi.Org/10.33541/Jmp.V10i1.3262

Udayani, K. M., \& Kusmariyatni, N. (2016). Penerapan Model Pembelajaran Predict-Observe-Explain (Poe) Untuk Meningkatkan Hasil Belajar Ipa Siswa. Mimbar Pgsd ..., 4(1), 1-10. Https://Ejournal.Undiksha.Ac.Id/Index.Php/JJPGSD/Article/View/7459

Yunitasari, R., \& Hanifah, U. (2020). Pendidikan Pengaruh Pembelajaran Daring Terhadap Minat Belajar Siswa Pada Masa COVID-19. Edukatif: Jurnal Ilmu Pendidikan, 2(3), 232-243. 